\title{
ADVANCES IN HANDLING SMALL RADIOCARBON SAMPLES AT THE LABORATOIRE DE MESURE DU CARBONE 14 IN SACLAY, FRANCE
}

\author{
E Delqué-Količ $\check{c}^{1,2} \cdot \mathrm{I} \mathrm{Caffy}^{1} \bullet \mathrm{C}$ Comby-Zerbino ${ }^{1} \cdot \mathrm{JP}^{\mathrm{P}}$ Dumoulin $^{1} \bullet \mathrm{S} \mathrm{Hain}^{1} \bullet \mathrm{M}^{\text {Massault }}{ }^{3} \bullet$

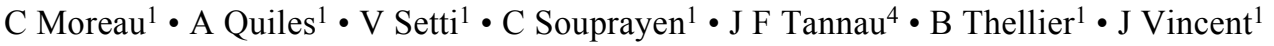

ABSTRACT. The Artemis accelerator mass spectrometry (AMS) facility, installed in 2003 in Saclay, France, is devoted to radiocarbon measurements. Samples are submitted by scientists in the fields of Quaternary geology, environmental sciences, and archaeology. The entire preparation process, originally optimized for samples with about $1 \mathrm{mg}$ of carbon, has been tested in recent years for samples with a lower carbon content. In particular, we prepared and measured carbonate and organic background and reference samples ranging in mass from 0.01 to $1 \mathrm{mg} \mathrm{C}$. These tests helped define our protocol's practical limits and determine necessary improvements. Furthermore, our experiments demonstrated that satisfactory graphitization yields ( $80 \%$ and higher) and low background values can be obtained with samples down to $0.2 \mathrm{mg}$ of carbon. For handling smaller samples, we developed a specific process. We tested smaller reactors $(5 \mathrm{~mL}$ in volume $)$ and adapted the reduction parameters $\left(\mathrm{H}_{2}\right.$ pressure and temperature) accordingly. We also tested the effect of a chemical water trap on graphitization yields and ${ }^{14} \mathrm{C}$ results. This paper presents in detail the aforementioned developments and reports the ${ }^{14} \mathrm{C}$ results obtained for background and standard small samples prepared with the modified reactors.

\section{INTRODUCTION}

The LMC14 laboratory in Saclay, France, routinely measures $\sim 4500$ radiocarbon samples a year for French agency interdisciplinary research programs in fields such as environmental sciences, archaeology, and hydrology. In recent years, there has been a growing interest for measurements of samples smaller than $0.1 \mathrm{mg} \mathrm{C}$, namely specific soil compounds and organic water fractions. Many laboratories have worked on the subject of very small samples and published papers proposing new protocols for preparations and measurements (Pearson et al. 1998; Hua et al. 2004; Santos et al. 2004, 2007; Ertunç et al. 2005; Smith et al. 2007; De Rooij et al. 2010). Our first attempt was to evaluate our capability to graphitize and to measure $\mu \mathrm{g}$-size samples using our standard graphitization line setup and our Artemis AMS facility based on a 3MV NEC Pelletron. In a recent paper, we presented the results obtained with our 2 standard graphitization lines when preparing samples down to $0.02 \mathrm{mg}$ of carbon (Delqué-Količ et al. 2013). Both lines are equipped with 12 reactors, but the reduction volume is $18 \mathrm{~mL}$ for the first line and $12 \mathrm{~mL}$ for the second.

Graphitization is performed by hydrogen reduction of $\mathrm{CO}_{2}$ gas over an iron powder catalyst at a reaction temperature of $600^{\circ} \mathrm{C}$. To trap the water formed during reduction, cold fingers immersed in liquid nitrogen are fitted with heating coils to maintain a trapping temperature of $-70{ }^{\circ} \mathrm{C}$. Carbonate (IAEA-C1) and charcoal (wood charcoal older than 70,000 BP) background samples are measured to quantify the modern contamination (normalized ${ }^{14} \mathrm{C}$ concentration ratio ${ }^{14} \mathrm{a}_{\mathrm{N}}=100 \%$ ) (Mook and van der Plicht 1999) due to chemical pretreatment, carbon extraction (by combustion or hydrolysis), and graphitization. To assess the dead carbon contamination, several small HOxI samples are prepared and measured under identical conditions. Applying the formula of Santos et al. (2007), the dead carbon contamination $d$ varies between 0.1 and $1 \mu \mathrm{g}$ and the modern carbon contamination $m$ ranges from 0.3 to $2 \mu \mathrm{g}$. Using these background estimates, the corrected ${ }^{14} \mathrm{C}$ concentration ratios

${ }^{1}$ LMC14, CEA Saclay, Bâtiment 450 porte 4E, 91191 Gif sur Yvette, France.

${ }^{2}$ Corresponding author. Email: emmanuelle.delque-kolic@cea.fr.

${ }^{3}$ IDES, UMR 8148 CNRS, Université Paris-Sud11, Bâtiment 504, Rue du Belvédère, Campus Universitaire d’Orsay, 91405 Orsay Cedex, France

${ }^{4}$ LSCE, CEA/DSM, Domaine du CNRS, Bâtiment 12, 91198 Gif sur Yvette, France. 


\section{E Delqué-Količ et al.}

${ }^{14} \mathrm{a}_{\mathrm{N}}$ of certain standard samples prepared with our regular lines were consistent with the consensus value (Delqué-Količ et al. 2012). However, $15 \%$ of the samples containing $<0.1 \mathrm{mg}$ of carbon nevertheless saw a dramatic drop in graphitization yields (below 70\%) with the consequence of poor ${ }^{12} \mathrm{C}^{3+}$ beam currents and large fractionation effects.

To improve the graphitization yields of the small samples, we reduced the volume of the reactors. Then, the pressure of gas is higher in smaller volumes, making it easier to follow the reaction process and to stop it at the right moment. A smaller-volume reactor also reduces the $\mathrm{CO}_{2}$ sample's contact with the inner surface of the cell, leading to both a shorter reaction time and less contamination. We also decided to test a chemical $\left(\mathrm{Mg}\left(\mathrm{ClO}_{4}\right)_{2}\right)$ water trap instead of using the technically restricting multitemperature device.

This article presents the graphitization yields obtained in these new reactors with samples down to $6 \mu \mathrm{g} \mathrm{C}$. Modern and dead carbon contaminations estimated from the measurements of ${ }^{14} \mathrm{C}$-free and HOxI samples are compared to the levels of contamination observed with the larger reactors. Finally, the ${ }^{14} \mathrm{C}$ concentration ratios of samples of IAEA-C2 are presented as a test case of the whole process of preparation and measurement developed for the very small samples.

\section{METHODS}

The design of the smaller reactor is very similar to that of the regular apparatus; the reactor's inner diameter is narrower, however, and a smaller pressure transducer with a lower pressure range (Omega PX72-015AV, 0-350 mbar) is used for more accurate measurements. The volume of the small reactor is $5 \mathrm{~mL}$, which represents a reduction of more than $50 \%$ from the volume of the regular reactors (Figure 1).

Figure 1 Schematics of the regular graphitization reactors used in the LMC14. The pressure transducer is situated just above the cold finger and the vacuum transducer is hooked up to the line immediately after the $\mathrm{CO}_{2}$ ampoule.

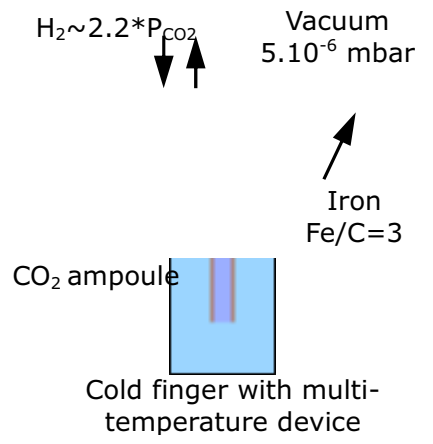

The mass of iron powder used (Merck GR for Analysis, particle size $10 \mu \mathrm{m}$ ) is 3 times greater than the expected mass of carbon. However, when a sample's mass is $<0.5 \mathrm{mg} \mathrm{C}$, the $3: 1$ ratio produces extremely thin cathodes that are rapidly consumed under the Cs beam bombardment in the accelerator ion source. After several tests, a mass of $1.5 \mathrm{mg}$ of iron is used for samples under $0.5 \mathrm{mg} \mathrm{C}$ (Delqué-Količ et al. 2012). This quantity facilitates the pressing of the $\mathrm{C} / \mathrm{Fe}$ powder. Under these conditions, ${ }^{12} \mathrm{C}^{3+}$ beam currents between 6 and $8 \mu \mathrm{A}$ are obtained for $20-\mu \mathrm{g}$ C samples.

The $\mathrm{H}_{2}$ to $\mathrm{CO}_{2}$ ratio is around 2.2 and never higher than 2.3 to avoid the formation of $\mathrm{CH}_{4}$ (Rinyu et al. 2007). The reduction temperature for handling "normal" size samples is $600^{\circ} \mathrm{C}$. As a lower temperature is generally advisable for preparing small samples (Turnbull et al. 2010), we first performed a few graphitizations at 450,500 , and $550{ }^{\circ} \mathrm{C}$ with $0.02-, 0.05-$, and $0.1-\mathrm{mg} \mathrm{C}$ samples in order to choose the best temperature for our forthcoming experiments. Whatever the temperature, no 
significant differences were observed in the graphitization yields. So, it was decided to use a reduction temperature of $550{ }^{\circ} \mathrm{C}$ for our experiments.

Two reactors have been tested. The first one is equipped with a multitemperature device to trap water produced during the reaction. The volume of the reactor having been greatly reduced, the temperature gradient between the reduction area and the multitemperature device (water trap) is more difficult to maintain. Indeed, with this smaller setup, the high temperature $\left(550^{\circ} \mathrm{C}\right)$ of the reduction tube interferes with the "cold zone" needed to trap the water. Thus, we decided to lower the water trap temperature to $-80^{\circ} \mathrm{C}$.

The second small reactor is fitted with a tube containing flakes of magnesium perchlorate anhydrous $\left(\mathrm{Mg}\left(\mathrm{ClO}_{4}\right)_{2}\right.$ from ThermoScientific). Some 10 to $20 \mathrm{mg}$ of $\mathrm{Mg}\left(\mathrm{ClO}_{4}\right)_{2}$ were put in the glass tube hooked up to the reactor. The flakes were changed with each new sample.

A set of 29 aliquots of $\mathrm{CO}_{2}$ taken from a large volume of $\mathrm{CO}_{2}$ prepared from IAEA-C6 sucrose enabled us to assess the graphitization yields and reaction times in the conditions described above. Graphitization was monitored by both pressure yield and gravimetric yield measurements. As shown by Rinyu et al. (2007), competing reactions, in particular the production of $\mathrm{CH}_{4}$ gas, can result in a satisfactory pressure yield while masking a poor graphitization reaction.

The pressure yield data is obtained from the following equation:

$$
\text { Pressure yields }(\%)=100\left(\left(\mathrm{P}_{\mathrm{CO} 2}+\mathrm{P}_{\mathrm{H} 2}-\mathrm{P}_{\text {total final }}\right) / 3 \mathrm{P}_{\mathrm{CO} 2}\right)
$$

where $\mathrm{P}_{\mathrm{CO} 2}$ is the initial pressure of $\mathrm{CO}_{2}$ gas in the reactor before graphitization, $\mathrm{P}_{\mathrm{H} 2}$ is the pressure of hydrogen introduced for the reduction, and $\mathrm{P}_{\text {total final }}$ is the final pressure of gas remaining when the pressure stops dropping.

The gravimetric yield is the ratio of the carbon mass converted to graphite $\left(\mathrm{Mc}_{\text {(graphite) }}\right)$ to the carbon mass in the $\mathrm{CO}_{2}$ gas before the graphitization $\left(\mathrm{Mc}_{(\mathrm{CO} 2)}\right)$ :

$$
\text { Gravimetric yield (\%) } \left.=100\left(\mathrm{Mc}_{(\text {graphite }}\right) \mathrm{Mc}_{(\mathrm{CO} 2)}\right)
$$

In the present case, $\mathrm{Mc}_{\text {(graphite) }}$ was obtained by combusting the $\mathrm{Fe} / \mathrm{C}$ mixture in an elemental analyzer (EA-IRMS analysis performed by the Service Central d'Analyse du CNRS - Solaize, France). The term $\mathrm{Mc}_{(\mathrm{CO} 2)}$ was calculated from $\mathrm{P}_{\mathrm{CO} 2}$ based on a calibration curve established from the pressure measurements of known quantities of carbon in our reactors. EA-IRMS measurements performed on these 29 graphite samples were used to evaluate whether isotopic fractionations occur during the reduction of $\mathrm{CO}_{2}$ gas in our new reactors.

To test the entire sample preparation process, small quantities of IAEA-C1 and IAEA-C2 carbonates (between 0.5 and $1 \mathrm{mg}$ ) were hydrolyzed in our regular preparation line (Cottereau et al. 2007), graphitized with our new reactors and then measured for ${ }^{14} \mathrm{C}$ content. A large volume of $\mathrm{CO}_{2}$ prepared from HOxI oxalic acid standard supplied several aliquots of $\mathrm{CO}_{2}$ for our experimental graphitizations. The IAEA-C1 and HOxI graphite samples allowed us to control the new graphitization cells' background levels (respectively, modern and dead carbon contaminations).

\section{RESULTS}

\section{Graphitization Yield}

As observed by Rinyu et al. (2007), the gravimetric yield gives smaller values than the pressure yield for a large majority of samples (Table 1). This behavior is caused by competing reactions that 


\section{E Delqué-Količ et al.}

lead to the formation of $\mathrm{CH}_{4}$ and/or $\mathrm{CO}$. In the present case, it can also be explained by the gravimetric yield calculation method. When the $\mathrm{Fe} / \mathrm{C}$ powder is removed from the tube and placed in the elemental analyzer, residues on the inside of the tube may minimize the quantity of carbon measured. Furthermore, the differences between both yields are probably increased by the high uncertainty of the $\mathrm{Mc}_{\text {(graphite) }}$ term. At any rate, the gravimetric and pressure yields are higher for samples graphitized in the small reactors with the $\mathrm{Mg}\left(\mathrm{ClO}_{4}\right)_{2}$ trap (Figure 2). This trend is confirmed by the $\delta^{13} \mathrm{C}$ values, which are closer to the IAEA-C6 consensus value $\left(\delta^{13} \mathrm{C}=-10.8 \%\right)$ for samples graphitized in the small-volume reactor equipped with the alternative water trap.

Table 1 Experimental results for IAEA-C6 samples.

\begin{tabular}{llllcc}
\hline $\begin{array}{l}\text { Type of graphitization } \\
\text { reactor }\end{array}$ & $\begin{array}{l}\text { Mass of } \\
\text { carbon }(\mu \mathrm{g})\end{array}$ & $\begin{array}{l}\text { Reaction } \\
\text { time }(\mathrm{min})\end{array}$ & $\begin{array}{l}\text { Gravimetric } \\
\text { yield }(\%)\end{array}$ & $\begin{array}{l}\text { Pressure } \\
\text { yield }(\%)\end{array}$ & $\begin{array}{l}\delta^{13} \mathrm{C}(\%) \\
\pm 0.3 \%\end{array}$ \\
\hline Large-volume reactor + & 353 & 240 & 89 & 72 & -8.5 \\
cryogenic trap at $-80{ }^{\circ} \mathrm{C}$ & 61 & 180 & 66 & 80 & -10.3 \\
& 45 & 195 & 66 & 83 & -11.2 \\
& 40 & - & 32 & 86 & -14.7 \\
& 29 & 180 & 62 & 101 & -10.5 \\
& 17 & 110 & 48 & 65 & -17.5 \\
\hline Small-volume reactor + & 239 & 150 & 41 & 80 & -12.4 \\
cryogenic trap at $-80^{\circ} \mathrm{C}$ & 177 & 150 & 105 & 67 & -11.8 \\
except* at $-100{ }^{\circ} \mathrm{C}$ & 56 & 190 & 118 & 66 & -14.1 \\
& 53 & 90 & 65 & 77 & -10.3 \\
& 47 & 150 & 47 & 99 & -13.0 \\
& 40 & 120 & 64 & 73 & -11.0 \\
& 30 & 90 & 75 & 116 & -15.5 \\
& $16^{*}$ & 100 & 31 & 75 & -11.2 \\
& $13 *$ & 45 & 56 & 72 & -14.7 \\
& 12 & 60 & 47 & 77 & -15.6 \\
& 12 & 90 & 44 & 21 & -10.0 \\
& 11 & 50 & 62 & 71 & -15.5 \\
& 11 & 60 & 60 & 24 & -16.4 \\
& $11 *$ & 60 & 66 & 85 & -13.1 \\
\hline $\mathrm{Small-volume} \mathrm{reactor}+$ & 36 & 40 & 70 & 106 & -10.8 \\
$\mathrm{Mg}\left(\mathrm{ClO}_{4}\right)_{2}$ trap & 32 & 60 & 92 & 71 & -10.7 \\
& 29 & 85 & 85 & 91 & -10.6 \\
& 14 & 90 & 81 & 87 & -11.1 \\
& 13 & 30 & 46 & 50 & -12.5 \\
& 10 & 90 & 110 & 87 & -11.2 \\
& 8 & 80 & 102 & 90 & -9.5 \\
& 6 & 60 & 76 & 93 & -17.0 \\
\hline
\end{tabular}

\section{Reaction Time and Reduction Temperature}

We usually define the reaction time as the time needed to obtain a plateau in the pressure curve. The reaction times of very small samples are generally shorter than those of regular-size samples. In Table 1, we observe that samples between 0.01 and $0.06 \mathrm{mg} \mathrm{C}$ graphitized in our large-volume cells have reaction times of 2 to $3 \mathrm{hr}$, whereas regular-size samples have reaction times of 4 to $5 \mathrm{hr}$ 


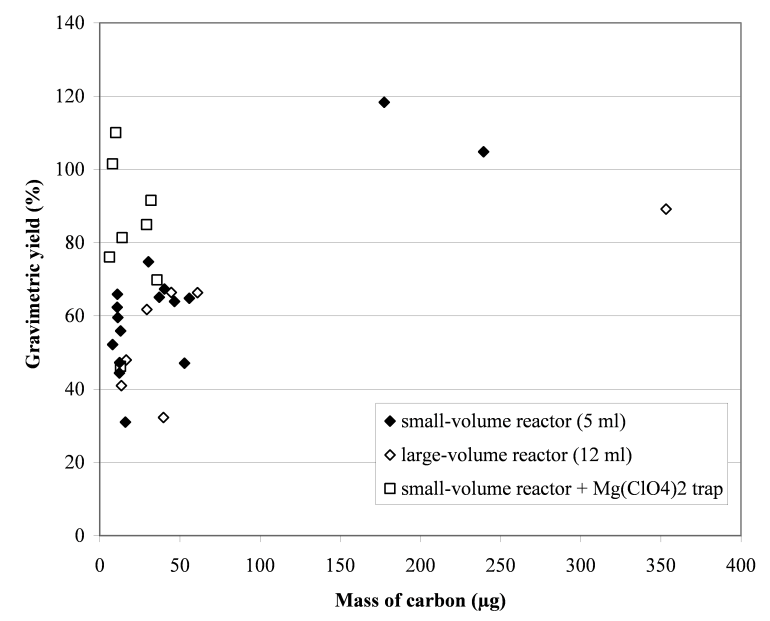

Figure 2 Gravimetric yield data for different carbon masses graphitized in 3 different types of reactors.

(Delqué-Količ et al. 2012). In the 5 - $\mathrm{mL}$ reactors, reaction times vary between $45 \mathrm{~min}$ and $2.5 \mathrm{hr}$ for samples between 0.01 and $0.06 \mathrm{mg} \mathrm{C}$. The smaller volume of the reaction cell has clearly minimized the reaction time. The system for trapping water, we further note, does not seem to affect the reaction time.

We also observe that the pressure of 4 samples with carbon masses below or close to $10 \mu \mathrm{g}$ flattens out after 10 min (Figure 3). Three of these samples were graphitized in the reactor with the water chemical trap. Reducing the reaction temperature from 550 to $500{ }^{\circ} \mathrm{C}$ enables graphitization to start up again. Even if we cannot explain this effect, it corroborates the observation made by others (Santos et al. 2007; Turnbull et al. 2010), that low reaction temperatures produce the best graphitization yields for samples under $10 \mu \mathrm{g} \mathrm{C}$. It appears necessary to perform some more experiments at 500 and $450{ }^{\circ} \mathrm{C}$ for samples close to and below $10 \mu \mathrm{g} \mathrm{C}$ to check if lower temperatures improve significantly the reaction time and/or the graphitization yield.

\section{AMS ${ }^{14} \mathrm{C}$ Measurements}

With routine measurements (graphite targets of $0.2-1 \mathrm{mg} \mathrm{C}$ ), the ${ }^{12} \mathrm{C}$ current out of the source is in the range $20-50 \mu \mathrm{A}$. The cathodes are generally submitted to 10 runs of 3 min each. For smaller samples $(<0.2 \mathrm{mg} \mathrm{C})$, the Cs ion flow that generates the ${ }^{12} \mathrm{C}$ beam current in the MC-SNICS cesium sputter ion source of the AMS facility is reduced to avoid quick deterioration of the samples under the beam. In this way, graphite targets last longer and 7 to 10 runs can be used for calculations. The ${ }^{12} \mathrm{C}$ beam currents measured for samples ranging from 0.01 to $0.2 \mathrm{mg} \mathrm{C}$ are between 1.5 and $20 \mu \mathrm{A}$. The ${ }^{14} \mathrm{C} /{ }^{12} \mathrm{C}$ ratios are corrected for fractionation with the AMS-measured $\delta^{13} \mathrm{C}$ values and normalized to an averaged value of 3 to four 1-mg C HOxI samples measured in the same batch. We observed, as others did (von Reden et al. 1998; Santos et al. 2007), a mass-dependent fractionation effect for samples under $0.1 \mathrm{mg} \mathrm{C}$. The AMS-measured $\delta^{13} \mathrm{C}$ results are lighter and can differ as much as 10 to $20 \%$ from the expected values. The data are not corrected for machine background. In fact, the machine blank, regularly measured with targets made of natural geological graphite, has an average ${ }^{14} \mathrm{C}$ concentration ratio of $0.015 \%$ which is considered negligible. 


\section{E Delqué-Količ et al.}

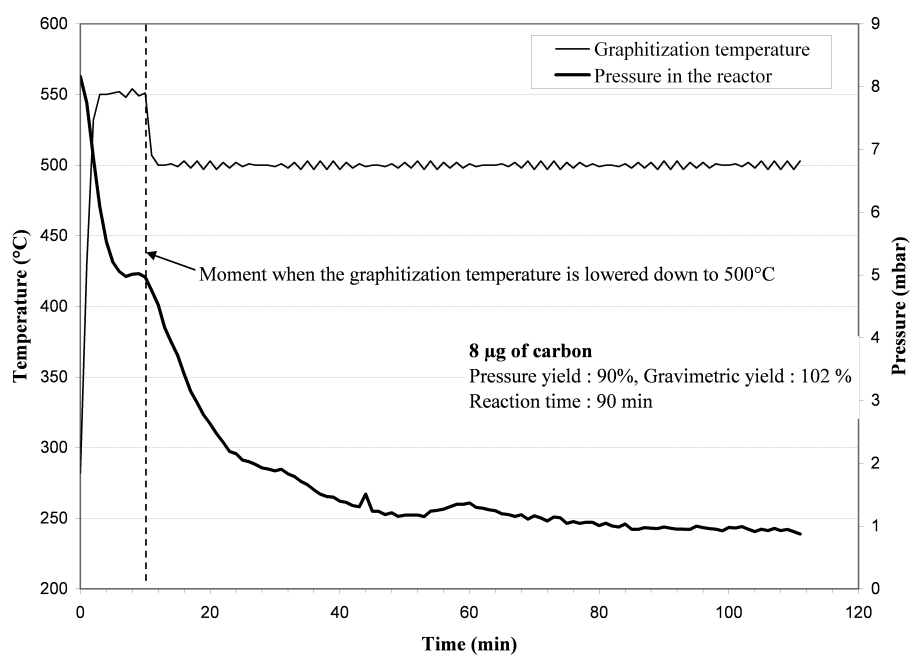

Figure 3 Graphitization curves for a sample containing $8 \mu \mathrm{g}$ of carbon in the small-volume reactor with the $\mathrm{Mg}\left(\mathrm{ClO}_{4}\right)_{2}$ trap. When the reduction temperature is changed from 550 to $500{ }^{\circ} \mathrm{C}$, the pressure drops again. The reaction time is the time needed to obtain a plateau in the pressure curve.

\section{Background Levels}

The ${ }^{14} \mathrm{C}$ activities of ${ }^{14} \mathrm{C}$-free samples (IAEA-C1 carbonate and ${ }^{14} \mathrm{C}$-free wood charcoal) assessed with our different graphitization line setups are plotted in Figure $3 \mathrm{a}$. Figure $3 \mathrm{~b}$ presents the deviations of normalized ${ }^{14} \mathrm{C}$ concentration ratios from the recommended value $\left({ }^{14} \mathrm{a}_{\mathrm{N}}=105.26 \%\right)$ for HOxI standard samples.

Presenting background results as such distinctly emphasizes the mass ranges of modern and dead carbon introduced in our samples over the course the entire preparation process. The data obtained with the small-volume reactors for IAEA-C1 samples fit the modern contamination range of 0.1 to $1 \mu \mathrm{g}$ defined with previous values of ${ }^{14} \mathrm{C}$-free samples graphitized in the large-volume reactors. Nevertheless, 8 values are above the $0.3-\mu \mathrm{g}$ solid line that represents the higher level of modern contamination for IAEA-C1 samples reduced in the $12-\mathrm{mL}$ reactors. As the vacuum level is the same in both the new cells and the standard reactors $\left(5 \times 10^{-6} \mathrm{mbar}\right)$, we suspect that the higher levels were caused by the hydrolysis step of the carbonate samples. In fact, in the large reactors, we graphitized small aliquots of $\mathrm{CO}_{2}$ sampled from a large batch of gas prepared from a large amount of IAEA-C1 carbonate $(20 \mathrm{~g})$. In this case, the amount of modern contamination present in each of the aliquots is only a fraction of the total contamination added when preparing the large IAEA-C1 sample. It can be considered that this fraction of modern contamination is smaller than the amount of contamination added when preparing separately small samples as was done for $\mathrm{CO}_{2}$ graphitized in the small reactors.

The water removal method (cryogenic or chemical) does not seem to have any effect on the level of modern contamination. The HOxI samples fall into the higher part of the dead carbon range previously defined with the large reactors; 2 values are even above $1 \mu \mathrm{g}$ of dead carbon. The iron powder may be responsible for these higher values. The catalyst used for these experiments and the one used for the graphitizations in the large reactors are from different batches. Nevertheless, as all of the samples processed in the small-volume reactors were measured in the same batch, a machine effect 
could also explain these higher ${ }^{14} \mathrm{C}$ concentration ratios. The water chemical trap does have any effect of the level of ${ }^{14} \mathrm{C}$-free contamination, compared to the cryogenic water trap.
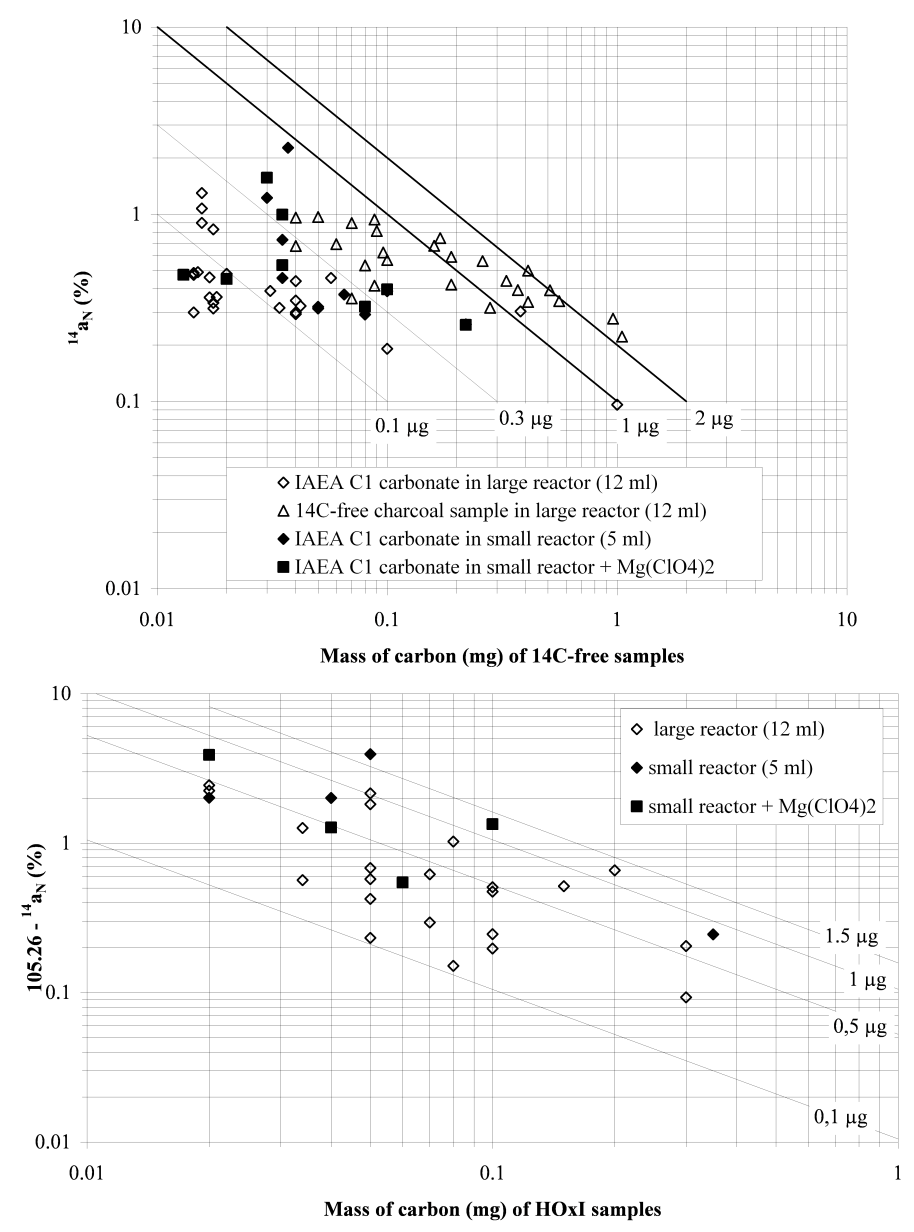

Figure 4 The normalized ${ }^{14} \mathrm{C}$ concentration ratio of the background as a function of the sample size. (A, top) IAEA-C1 samples and ${ }^{14} \mathrm{C}$-free wood charcoal samples. The solid lines represent fixed amounts of modern carbon. (B, bottom) Deviation of the normalized ${ }^{14} \mathrm{C}$ concentration ratio from the standard value $\left(105.26-{ }^{14} a_{N}\right)$ of the HOxI standard as a function of the sample size. The solid lines represent fixed amounts of dead carbon.

\section{Results for IAEA-C2 Samples}

Four samples of IAEA-C2 were prepared with the small reactors and measured in the same batch of IAEA-C1 and HOxI samples (Figure 5). The ${ }^{14} \mathrm{C} /{ }^{12} \mathrm{C}$ ratios were corrected for fractionation and normalized as explained in the previous paragraph. The raw results were corrected using the approach described by Santos et al. (2007). Background corrections of $m=0.5 \pm 0.5 \mu \mathrm{g}$ and $d=0.5 \pm 0.5 \mu \mathrm{g}$ were applied, consistent with the values calculated in this specific batch of measurement. The error bars represent the error for background correction and the standard deviation $\sigma$. All the results are consistent with the consensus value. 


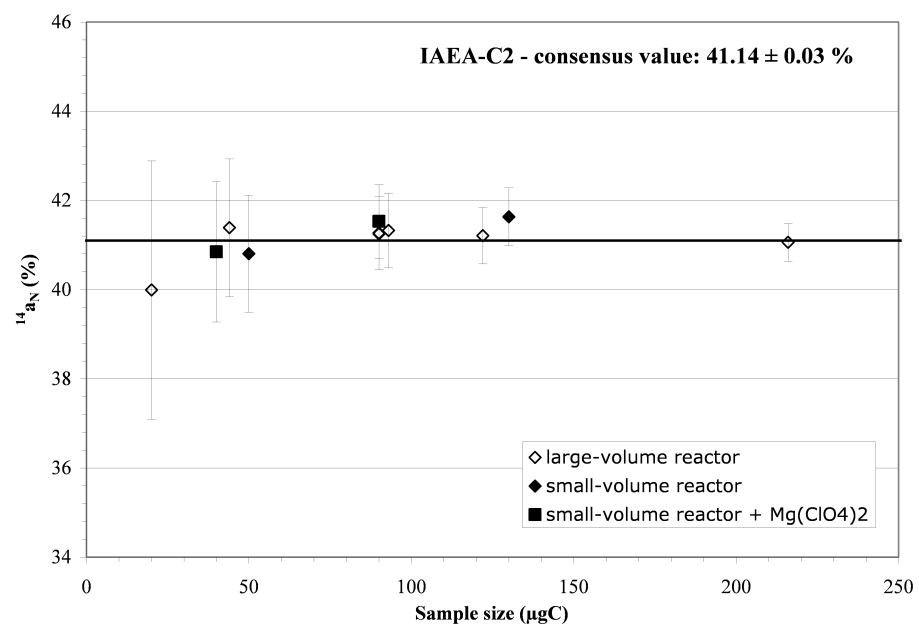

Figure 5 The normalized ${ }^{14} \mathrm{C}$ concentration ratio of IAEA-C2 as a function of sample size.

\section{CONCLUSION}

Increasing demands for ${ }^{14} \mathrm{C}$ measurements of very small samples gave us the opportunity to test the limits of our standard graphitization lines. It was clear that new reactors needed to be designed for samples below $0.1 \mathrm{mg} \mathrm{C}$. As demonstrated in the present paper, for samples below $0.1 \mathrm{mg} \mathrm{C}$, the 5$\mathrm{mL}$ volume reactor equipped with a $\mathrm{Mg}\left(\mathrm{ClO}_{4}\right)_{2}$ water trap gives higher graphitization yields than the same volume reactor equipped with a cryogenic water trap at -80 or $-100^{\circ} \mathrm{C}$. The reaction time does not seem to be modified by the type of water trapping. The graphitization temperature was lowered from $600{ }^{\circ} \mathrm{C}$ for $1-\mathrm{mg}$ samples in large reactors to $550^{\circ} \mathrm{C}$ for samples under $0.1 \mathrm{mg} \mathrm{C}$ in small reactors. At this temperature, graphitization yields are satisfactory for samples down to $10 \mu \mathrm{g} \mathrm{C}$. Below or close to $10 \mu \mathrm{g} \mathrm{C}$, we observe that the reaction flattens and starts up again by reducing the temperature to $500{ }^{\circ} \mathrm{C}$. Further experiments at $500{ }^{\circ} \mathrm{C}$ and below are necessary to conclude definitely on the interest of lowering the graphitization temperature for samples close to and smaller than $10 \mu \mathrm{g} \mathrm{C}$.

With our small reactors, the modern carbon contamination is between 0.1 and $1 \mu \mathrm{g}$. These values are satisfactory but more dispersed and slightly higher than with the large reactors. This behavior, which can be explained by our preparation protocol of the IAEA-C1 samples, shows that the first steps of preparation (cleaning and hydrolysis step) could be improved for small samples.

The dead carbon contamination is between 0.5 and $1 \mu \mathrm{g}$ when samples are graphitized in our small reactors. These values are in the higher part of the range defined with the large reactors. This may be due to the iron catalyst, but, as all the samples have been measured in the same batch, a machine effect is suspected. The ${ }^{14} \mathrm{C}$-free and HOxI samples graphitized in the 5 -mL reactor equipped with the chemical water trap do not show higher modern and dead contamination levels than the same samples processed in the reactor equipped with the cryogenic trap. Furthermore, the use of a chemical water trap avoids the fastidious supplying of liquid nitrogen throughout the entire reaction process and could be an efficient solution to trap water during the graphitization of samples close to and below $0.1 \mathrm{mg} \mathrm{C}$.

The 4 samples of IAEA-C2 ranging from 0.04 to $0.13 \mathrm{mg} \mathrm{C}$ graphitized in the small reactors have been successfully prepared and measured. The normalization to 1-mg C HOxI standards, the AMS 
$\delta^{13} \mathrm{C}$ corrections, and the background corrections applied for dead and modern contamination lead to results in good agreement with the consensus value. Nevertheless, very small samples $(<0.04 \mathrm{mg} \mathrm{C})$ still need to be tested in the small reactors.

In conclusion, we plan to use the $5-\mathrm{mL}$ volume reactor equipped with the water chemical trap to graphitize samples from 0.04 to $0.1 \mathrm{mg} \mathrm{C}$. To evaluate as precisely as possible the modern and dead carbon contaminations associated to the unknown samples, background samples of matched size will also be prepared, graphitized, and measured in the same way. As shown in our study with the IAEA-C2 samples, good results are obtained when the ${ }^{14} \mathrm{C}$ ratios are corrected for fractionation with the AMS-measured $\delta^{13} \mathrm{C}$ values and normalized to an averaged value of several $1 \mathrm{mg} \mathrm{C}$ HOxI. We will use this protocol to calculate ${ }^{14} \mathrm{C}$ results for the small samples.

\section{ACKNOWLEDGMENTS}

This work was supported by CNRS, CEA, IRD, IRSN, and the Ministère de la Culture et de la Communication.

\section{REFERENCES}

Cottereau E, Arnold M, Moreau C, Baqué D, Bavay D, Caffy I, Comby C, Dumoulin JP, Hain S, Perron M, Salomon J, Setti V. 2007. Artemis, the new ${ }^{14}$ C AMS at LMC14 in Saclay, France. Radiocarbon 49(2):2919.

Delqué-Količ E, Comby-Zerbino C, Ferkane S, Moreau C, Dumoulin JP, Caffy I, Souprayen C, Quilès A, Bavay D, Hain S, Setti V. 2013. Preparing and measuring ultra-small radiocarbon samples with the ARTEMIS AMS facility in Saclay, France. Nuclear Instruments and Methods in Physics Research B 294:18993.

De Rooij M, van der Plicht J, Meijer HAJ. 2010. Porous iron pellets for AMS ${ }^{14} \mathrm{C}$ analysis of small samples down to ultra-microscale size $(10-25 \mu \mathrm{g})$. Nuclear Instruments and Methods in Physics Research B 268(78):947-51.

Ertunç T, Xu S, Bryant CL, Maden C, Murray C, Currie M, Freeman SPHT. 2005. Progress in AMS target production of sub-milligram samples at the NERC radiocarbon laboratory. Radiocarbon 47(3):453-64.

Hua Q, Zoppi U, Williams AA, Smith AM. 2004. Smallmass AMS radiocarbon analysis at ANTARES. $\mathrm{Nu}$ clear Instruments and Methods in Physics Research B 223-224:284-92.

Mook WG, van der Plicht J. 1999. Reporting ${ }^{14} \mathrm{C}$ activities and concentrations. Radiocarbon 41(3):227-39.

Pearson A, McNichol AP, Schneider RJ, von Reden KF. 1998. Microscale AMS ${ }^{14} \mathrm{C}$ measurement at
NOSAMS. Radiocarbon 40(1):61-75.

Rinyu L, Futó I, Kiss ÁZ, Molnár M, Svingor É, Quarta G, Calcagnile L. 2007. Performance test of a new graphite target production facility in ATOMKI. Radiocarbon 49(2):217-24.

Santos GM, Southon JR, Druffel-Rodriguez KC, Griffin S, Mazon M. 2004. Magnesium perchlorate as an alternative water trap in AMS graphite sample preparation: a report on sample preparation at KCCAMS at the University of California, Irvine. Radiocarbon 46(1):165-73.

Santos GM, Southon JR, Griffin S, Beaupré SR, Druffel ERM. 2007. Ultra small-mass AMS ${ }^{14} \mathrm{C}$ sample preparation and analyses at KCCAMS/UCI Facility. $\mathrm{Nu}$ clear Instruments and Methods in Physics Research B 259(1):293-302.

Smith AM, Petrenko VV, Hua Q, Southon J, Brailsford G. 2007. The effect of $\mathrm{N}_{2} \mathrm{O}$, catalyst, and means of water vapor removal on the graphitization of small $\mathrm{CO}_{2}$ samples. Radiocarbon 49(2):245-54.

Turnbull J, Prior C, Graphitization Workshop Participants. 2010. Report on the 20th International Radiocarbon Conference Graphitization Workshop. Radiocarbon 52(3):1230-5.

von Reden KF, McNichol AP, Pearson A, Schneider RJ. 1998. ${ }^{14} \mathrm{C}$ AMS measurements of $<100 \mu \mathrm{g}$ samples with a high-current system. Radiocarbon 40(1):24753. 